\title{
Effect of Different Weed Management Practices on Growth and Yield of Tossa Jute (Corchorus olitorius) in the New Alluvial Zone of West Bengal, India
}

\author{
Madhab Kumar Datta ${ }^{1 *}$, Pronobesh Halder ${ }^{2}$, Utpal Biswas ${ }^{1}$ and Champak Kumar Kundu ${ }^{1}$ \\ ${ }^{1}$ Department of Agronomy, ${ }^{2}$ Department of Agricultural Entomolgy, Faculty of Agriculture, \\ Bidhan Chandra Krishi Viswavidyalaya, Mohanpur, Nadia, 741252, West Bengal, India \\ *Corresponding author
}

\begin{abstract}
Keywords
Jute, Weed

management,

Chemical, Botanical,

Hand weeding.

Article Info

Accepted:

10 September 2017

Available Online:

10 November 2017 different weed management practices on growth and yield of jute (cv. JRO-524). The experiment was designed with eight treatments (weed management practices) and tested under Randomized Block Design with three replications. The weed management practices comprised of different doses of chemical herbicides like Fenoxaprop-P-Ethyl and Quizalofop-Ethyl as post emergence spray at 30 DAS; botanical herbicides like Calotropis and Parthenium (5\% raw extract) as pre emergence spray at 1 DAS in combination with hand weeding. The highest jute fibre yield was recorded in hand weeding twice at 15 and 30 DAS (3.91 t ha ${ }^{-1}$ in 2010 and $3.98 \mathrm{t} \mathrm{ha}^{-1}$ in 2011) which was closely followed by Quizalofop-Ethyl @ $100 \mathrm{~g} \mathrm{ha}^{-1}$ at $30 \mathrm{DAS}+$ Hand weeding at15 DAS $\left(3.89 \mathrm{t} \mathrm{ha}^{-1}\right.$ in 2010 and $3.95 \mathrm{t} \mathrm{ha}^{-1}$ in 2011 respectively). The benefit cost ratio was highest in QuizalofopEthyl@100 $\mathrm{g} \mathrm{ha}^{-1}$ at 30 DAS + Hand weeding at15 DAS (1.96 in 2010 and 1.39 in 2011 respectively). From the present experiment, it can be concluded that the spraying of Quizalofop-Ethyl @ $100 \mathrm{~g} \mathrm{ha}^{-1}$ at 30 DAS + Hand weeding at 15 DAS would be beneficial practice to the jute farmer of West Bengal.
\end{abstract}

\section{A B S T R A C T}

A field experiment was conducted during pre-kharif season of 2010 and 2011 at the CBlock Farm of Bidhan Chandra Krishi Viswavidyalaya, Kalyani to find out the effect of

\section{Introduction}

Jute is one of the most important cash crops in the alluvial zone of West Bengal and neighbouring states. The hot and humid climate with intermittent rainfall during the jute sowing season (first fortnight of April) in alluvial plains encourage profuse weed growth (Saraswat, 1999) resulting severe weed infestation during the early crop growth phase in jute. It was also estimated that 75-80 $\%$ of fibre yield is lost due to weed infestation which is quite common in most of the jute growing situations (Sahoo and Saraswat, 1988). Therefore, weed free condition in the early stages of growth in jute always maintains higher productivity (Saraswat and Shanna, 1983). But about $35 \%$ of the total cost of production goes to weeding only if done manually (Saraswat, 1980) and thereby drastically reduce profitability. Only a few pre emergence herbicides found moderately effective to control jute weeds so far. Some recent findings showed that Quizalofop ethyl (5\% EC) as post emergence application could control only the grassy weeds (Ghorai et al., 2004; Bhattacharya et al., 2004). Fenoxapropethyl also showed promise for grass weed 
control in jute (Sarkar, 2006). Again Calotropis raw leaf and stem extracts has been used as herbicide and it has been found that the raw extract applied @ $5 \mathrm{ml} /$ litre of water as pre emergence in Soybean (Ghosh, 2008) and also in Paddy found useful to control grass and broadleaves categories of weeds. According to Ghosh et al., (2007), the Parthenium extracts are also useful as herbicides; $5 \%$ water extract is able to control the grassy weeds. Therefore, a field experiment was designed with an objective to find a more effective weed management practices through combination of chemical, botanical and mechanical methods for increasing crop growth and yield of jute in the lower Gangetic jute growing belt in the new alluvial plains of West Bengal.

\section{Materials and Methods}

A field experiment was conducted in Gangetic alluviam sandy loam neutral soil ( $\mathrm{pH}$ 6.9) at C-Block Farm of Bidhan Chandra Krishi Viswavidyalaya, Kalyani, Nadia $\left(23.5^{\circ} \mathrm{N}, 89^{\circ} \mathrm{E}\right.$ and $9.75 \mathrm{~m}$ altitude) during pre-kharif season of 2010 and 2011. The experiment was laid out in randomized block design (RBD), replicated thrice with seven treatments [Fenoxaprop-P-Ethyl @ $67.5 \mathrm{~g} \mathrm{ha}^{-1}$ at 30 DAS (days after sowing) + Hand Weeding at 15 DAS, Fenoxaprop-PEthyl @135.0 g ha ${ }^{-1}$ at $30 \mathrm{DAS}+$ Hand Weeding at 15 DAS, Quizalofop-Ethyl @ 50 $\mathrm{g} \mathrm{ha}^{-1}$ at $30 \mathrm{DAS}+$ Hand Weeding at $15 \mathrm{DAS}$, Quizalofop-Ethyl @ $100 \mathrm{~g} \mathrm{ha}^{-1}$ at 30 DAS + Hand Weeding at 15 DAS, Calotropis raw extract@5\% at 1 DAS + Hand Weeding at 30 DAS, Parthenium raw extract @ 5\% at 1 DAS + Hand Weeding at 30 DAS, Twice hand weeding at 15 DAS and 30 DAS, Unweeded control] in $5.0 \times 4.0 \mathrm{~m}$ size plots. Jute seed (JRO 524) was sown at a row spacing of $20 \mathrm{~cm}$ in the third week of April and harvested 120 days later. All other standard agronomic practices including plant protection measures recommended for Olitorius jute were followed. Herbicides were applied using 500 liters of water $\mathrm{ha}^{-1}$ with a flat fan nozzle attached in a high volume Knap sack sprayer as per schedule. Observations on plant population, plant height, leaf area index (LAI), stem girth size, phytotoxicity, fibre yield, stick yield were recorded and analyzed using the analysis of variance technique. The phyto-toxic rating was done on $15^{\text {th }}$ and $30^{\text {th }}$ days after spraying of herbicides (DASH) using 0 to 10 scale (0 indicates no adverse effect of herbicides on the crop, and 10 indicates $100 \%$ adverse effect of herbicides on the crop). Harvest index (Khandakar et al., 1985) and weed index (Gill, G.S. and Vijayakumar 1969) were calculated by using the following formula:

$$
\begin{aligned}
& \text { Harvest Index }(\mathrm{HI})=\frac{\text { Economic yield }}{\text { Biological yield }} \\
& \text { Yield of hand weeded plot }- \text { Yield of } \\
& \text { treated plot }
\end{aligned}
$$

Economic analysis was performed considering local market rates for inputs and the produce.

\section{Results and Discussion}

\section{Effect on yield attributing factors of jute plant}

The weed management treatments reflected a profound effect on growth and yield attributing characters of jute. Plant population was maximum in unweeded control. This is perhaps due to less interference caused during germination of jute seeds through mechanical injury and no phytotoxicity by the chemicals in unweeded control plots which resulted the highest plant population. Minimum plant 
population was recorded in treatment twice hand weeding at 15 DAS and 30 DAS which was followed by Quizalofop-Ethyl @ 100 g $\mathrm{ha}^{-1}+$ Hand Weeding at15 DAS. The other treatments where chemical and botanical herbicide were combined with hand weeding also resulted less plant population in comparison to the unweeded control (Table 1).

As similar result was observed in by Das et al., 2008 twice hand weeding at 15 DAS and 30 DAS resulted the highest plant height which was closely followed by QuizalofopEthyl @100 g ha ${ }^{-1}+$ Hand Weeding at 15 DAS in the both the year of experiment (396.31 cm in 2010 and $397.40 \mathrm{~cm}$ in 2011 respectively). This is due to lesser weed competition in those treatment plot resulted better growth of crops and plant height. The shortest plant height was found in unweeded control because of severe competition with the weeds for space, light, nutrients and water required for growth. The other yield attributing factors like leaf area index (LAI), stem girth size were also highest in case of twice hand weeding at 15 DAS and 30 DAS which was statistically at par with Quizalofop-Ethyl @ $100 \mathrm{~g} \mathrm{ha}^{-1}+$ Hand Weeding at 15 DAS and lowest in case of unweeded control.

For consecutive years stem girth size (upper, middle and lower) was also satisfactorily high in Fenoxaprop-P-Ethyl @ 135.0 g ha-1 + Hand weeding at 15 DAS. Here QuizalofopEthyl and Fenoxaprop -P-Ethyl when applied in combination with hand weeding shown minimum weed completion during the critical period of crop weed competition period providing ample of space for growth of jute as also noted by Sarkar, 2006. The observations taken in the experimental field on the basis of phytotoxicity rating scale (PRS) was prepared by visual scoring scale of $0-10$ indicated there was no phytotoxic symptom as epinasty/hyponasty, leaf yellowing, necrosis, stunting growth, wilting. All the crops looked healthy during experimental time in the experimental field. This result depicts that Quizalofop-Ethyl, Fenoxaprop-P-Ethyl do not show any phytotoxicity on jute crop rather increases the growth by reducing weed competition which was consistent with the finding of Ghorai et al., 2006.

\section{Effect on yield of jute}

Yield of jute fibre was recorded highest in case of twice hand weeding at 15 DAS and 30 DAS in both the year 2010 (3.91 t ha- ${ }^{1}$ ) and 2011 (3.98 $\mathrm{t} \mathrm{ha}^{1}$ ) respectively. QuizalofopEthyl @100 $\mathrm{g} \mathrm{ha}^{-1}+$ Hand Weeding at 15 DAS resulted comparable mean of fibre yield (3.89 $\mathrm{t} \mathrm{ha}^{-1}$ in 2010 and $3.95 \mathrm{t} \mathrm{ha}^{-1}$ in 2011 respectively) compared to hand weeding twice due to optimum plant population and other yield attributing factors like plant height, leaf area index, stem girth size. Among the other chemical treatments appreciable amount of yield was also obtained from Fenoxaprop-P-Ethyl @ $135.0 \mathrm{~g} \mathrm{ha}^{-1}+$ Hand Weeding at 15 DAS as similar trends in fibre yield of jute was found by Sarkar et al., 2013.

Botanical herbicide treatments failed to result any satisfactory yield during this experiments (Table 2). The weed management treatments thus imparted a prominent difference in the harvest index and weed index of jute crop in this experiment. Harvest index was highest in twice hand weeding at $15 \mathrm{DAS}$ and $30 \mathrm{DAS}$ followed by Quizalofop-Ethyl @100 g ha ${ }^{-1}+$ Hand Weeding at15 DAS.

This is also due to the lowest weed index recorded in Quizalofop-Ethyl @100 g ha ${ }^{-1}+$ Hand Weeding at 15 DAS only after twice hand weeding at 15 DAS and 30 DAS which favoured growth and yield of jute crop. 
Table.1 Effect of different weed management treatment on growth of jute

\begin{tabular}{|c|c|c|c|c|c|c|c|c|c|c|c|c|}
\hline \multirow{3}{*}{ Treatments } & \multirow{2}{*}{\multicolumn{2}{|c|}{$\begin{array}{l}\text { Plant } \\
\text { population } \mathbf{m}^{-2} \\
\text { at harvest }\end{array}$}} & \multirow{2}{*}{\multicolumn{2}{|c|}{$\begin{array}{c}\text { Leaf Area } \\
\text { Index (LAI) at } \\
90 \text { DAS }\end{array}$}} & \multirow{2}{*}{\multicolumn{2}{|c|}{$\begin{array}{c}\text { Plant } \\
\text { Height }(\mathrm{cm}) \\
\text { at harvest }\end{array}$}} & \multicolumn{6}{|c|}{ Stem Girth (cm) } \\
\hline & & & & & & & \multicolumn{2}{|c|}{ Upper } & \multicolumn{2}{|c|}{ Middle } & \multicolumn{2}{|c|}{ Bottom } \\
\hline & 2010 & 2011 & 2010 & 2011 & 2010 & 2011 & 2010 & 2011 & 2010 & 2011 & 2010 & 2011 \\
\hline $\begin{array}{l}\text { Fenoxaprop-P-Ethyl @ } 67.5 \mathrm{~g} \mathrm{ha}^{-1} \text { at } 30 \text { DAS + Hand } \\
\text { Weeding at15 DAS }\end{array}$ & 32.33 & 32.50 & 371.30 & 372.97 & 12.27 & 12.33 & 1.49 & 1.52 & 3.13 & 3.13 & 5.31 & 5.40 \\
\hline $\begin{array}{l}\text { Fenoxaprop -P-Ethyl @ } 135.0 \mathrm{~g} \mathrm{ha}^{-1} \text { at } 30 \mathrm{DAS}+\text { Hand } \\
\text { Weeding at15 DAS }\end{array}$ & 32.00 & 34.53 & 380.34 & 381.45 & 12.46 & 12.40 & 1.69 & 1.72 & 3.26 & 3.27 & 5.54 & 5.68 \\
\hline $\begin{array}{l}\text { Quizalofop-Ethyl @ } 50 \mathrm{~g} \mathrm{ha}^{-1} \text { at } 30 \text { DAS + Hand } \\
\text { Weeding at15 DAS }\end{array}$ & 30.00 & 29.48 & 374.68 & 374.29 & 12.35 & 12.22 & 1.56 & 1.61 & 3.21 & 3.20 & 5.49 & 5.60 \\
\hline $\begin{array}{l}\text { Quizalofop - Ethyl @ } 100 \mathrm{~g} \mathrm{ha}^{-1} \text { at } 30 \text { DAS + Hand } \\
\text { Weeding at15 DAS }\end{array}$ & 29.67 & 28.51 & 396.31 & 397.40 & 12.86 & 12.70 & 1.94 & 1.97 & 3.59 & 3.50 & 5.88 & 5.99 \\
\hline $\begin{array}{l}\text { Calotropis raw extract @ 5\% at } 1 \text { DAS + Hand Weeding } \\
\text { at30 DAS }\end{array}$ & 35.00 & 35.55 & 339.22 & 340.54 & 11.77 & 12.02 & 1.43 & 1.45 & 2.83 & 2.80 & 4.42 & 4.51 \\
\hline $\begin{array}{l}\text { Parthenium raw extract @ } 5 \% \text { at } 1 \text { DAS + Hand } \\
\text { Weeding at } 30 \text { DAS }\end{array}$ & 35.67 & 36.47 & 343.43 & 344.21 & 12.07 & 12.20 & 1.52 & 1.47 & 2.85 & 2.83 & 5.02 & 4.91 \\
\hline Twice hand weeding at 15 DAS and 30 DAS & 28.33 & 30.53 & 404.51 & 405.74 & 13.06 & 12.95 & 2.12 & 2.14 & 3.75 & 3.78 & 6.53 & 6.58 \\
\hline Unweeded control & 39.00 & 37.80 & 303.22 & 302.54 & 8.75 & 8.90 & 1.34 & 1.37 & 1.48 & 1.50 & 2.84 & 2.81 \\
\hline S.Em( $( \pm)$ & 0.81 & 0.12 & 0.21 & 0.84 & 0.21 & 0.11 & 0.07 & 0.01 & 0.1 & 0.02 & 0.13 & 0.06 \\
\hline C.D. $(5 \%)$ & 2.47 & 0.39 & 0.66 & 2.56 & 0.65 & 0.35 & 0.2 & 0.05 & 0.3 & 0.06 & 0.41 & 0.2 \\
\hline
\end{tabular}


Int.J.Curr.Microbiol.App.Sci (2017) 6(11): $1118-1123$

Table. 2 Effect of different weed management treatment on yield, benefit: cost ratio of jute

\begin{tabular}{|c|c|c|c|c|c|c|c|c|c|c|}
\hline \multirow[b]{2}{*}{ Treatments } & \multicolumn{2}{|c|}{$\begin{array}{c}\text { Fibre Yield } \\
\text { t ha }^{-1}\end{array}$} & \multicolumn{2}{|c|}{$\begin{array}{c}\text { Stick Yield } \\
\text { t ha }^{-1}\end{array}$} & \multicolumn{2}{|c|}{$\begin{array}{c}\text { Harvest Index } \\
(\%)\end{array}$} & \multicolumn{2}{|c|}{ Weed Index (\%) } & \multirow{2}{*}{$\begin{array}{c}\text { Benefit } \\
\text { : Cost } \\
\text { Ratio } \\
\text { for } \\
2010\end{array}$} & \multirow{2}{*}{$\begin{array}{c}\text { Benefit } \\
\text { : Cost } \\
\text { Ratio } \\
\text { for } \\
2011\end{array}$} \\
\hline & 2010 & 2011 & 2010 & 2011 & 2010 & 2011 & 2010 & 2011 & & \\
\hline $\begin{array}{l}\text { Fenoxaprop-P-Ethyl @ } 67.5 \mathrm{~g} \mathrm{ha}^{-1} \text { at } 30 \text { DAS + } \\
\text { Hand Weeding at15 DAS }\end{array}$ & 3.47 & 3.52 & 8.56 & 8.69 & 28.89 & 28.83 & 11.25 & 11.56 & 1.8 & 1.28 \\
\hline $\begin{array}{l}\text { Fenoxaprop -P-Ethyl @ } 135.0 \mathrm{~g} \mathrm{ha}^{-1} \text { at } 30 \text { DAS } \\
\text { + Hand Weeding at } 15 \text { DAS }\end{array}$ & 3.75 & 3.83 & 9.17 & 9.26 & 29.01 & 29.26 & 4.09 & 3.77 & 1.92 & 1.37 \\
\hline $\begin{array}{l}\text { Quizalofop-Ethyl @ } 50 \mathrm{~g} \mathrm{ha}^{-1} \text { at } 30 \text { DAS + } \\
\text { Hand Weeding at } 15 \text { DAS }\end{array}$ & 3.64 & 3.72 & 8.93 & 9.01 & 28.99 & 29.22 & 6.91 & 6.53 & 1.88 & 1.34 \\
\hline $\begin{array}{l}\text { Quizalofop - Ethyl @ } 100 \mathrm{~g} \mathrm{ha}^{-1} \text { at } 30 \text { DAS + } \\
\text { Hand Weeding at15 DAS }\end{array}$ & 3.89 & 3.95 & 9.41 & 9.46 & 29.28 & 29.46 & 0.51 & 0.75 & 1.96 & 1.39 \\
\hline $\begin{array}{l}\text { Calotropis raw extract @ 5\% at } 1 \text { DAS + Hand } \\
\text { Weeding at30 DAS }\end{array}$ & 2.89 & 2.99 & 7.68 & 7.81 & 27.39 & 27.69 & 26.09 & 24.87 & 1.46 & 1.06 \\
\hline $\begin{array}{l}\text { Parthenium raw extract @ } 5 \% \text { at } 1 \text { DAS + } \\
\text { Hand Weeding at } 30 \text { DAS }\end{array}$ & 2.98 & 3.04 & 8.16 & 8.28 & 26.76 & 26.86 & 23.79 & 23.62 & 1.54 & 1.10 \\
\hline Twice hand weeding at 15 DAS and 30 DAS & 3.91 & 3.98 & 9.38 & 9.50 & 29.41 & 29.53 & 0 & 0.00 & 1.71 & 1.22 \\
\hline Unweeded control & 2.01 & 2.12 & 5.1 & 5.27 & 28.26 & 28.69 & 48.59 & 46.73 & 1.2 & 0.89 \\
\hline S.Em( \pm$)$ & 0.04 & 0.01 & 0.08 & 0.02 & & & & & & \\
\hline C.D. $(5 \%)$ & 0.13 & 0.04 & 0.25 & 0.07 & & & & & & \\
\hline
\end{tabular}




\section{Economic analysis}

Among the treatments twice hand weeding at 15 DAS and 30 DAS gave the higher fibre yield and stick yield than Quizalofop-Ethyl @100 g ha-1 + Hand Weeding at15 DAS. But as hand weeding is labour intensive task and thus expensive compare to cost of chemical herbicide, Quizalofop-Ethyl @100 g ha-1 + Hand Weeding at 15 DAS recorded the highest B: C ratio (1.96 in 2010 and 1.39 in 2011) which was comparable with the finding of Das et al., 2008.

Considering the fibre yield and the benefit: cost ratio of the treatments in this experiments, it can be concluded that chemical methods combined with one hand weeding can replace hand weeding twice and bio herbicides. Among the treatments Quizalofop-Ethyl @100 g ha ${ }^{-1}+$ Hand Weeding at15 DAS gave the higher economic yield over the other methods like twice hand weeding (at 15\&30 DAS). It can further be concluded that Quizalofop-Ethyl @ $100 \mathrm{~g} \mathrm{ha}^{-1}+$ Hand Weeding at15 DAS is also superior over the twice hand weeding at 15 and 30 DAS as it gives higher cost-benefit ratio.

\section{References}

Bhattacluuya, S. P., Mondal, L., Pal, D. and Saha, M. 2004. Bio-efficacy of Targa super (quizalofop ethyl $5 \%$ EC) in controlling weeds of jute. Pestology 28 (4): 32-35.

Das, K., Guha B. and Zaman, A. S. N. 2008. Productivity and profitability of tossa jute (Corchorus Olitorius) under different weed management practices in Jute - Toria cropping system Madras Agric. J., 95 (712): 353-358. July-December.

Ghorai, A. K., Chakraborty, A. K., Pandit, N. C. and Mandai, R. K. 2006. Integrated Weed Management in Jute (Corchorus spp. L.)
Indian J. Weed Sci. 38 (I \& 2): 163-164.

Ghorai, A. K., Chakraborty, A. K., Pandit, N. C., Mondal, R. K. and Biswas, C. R. 2004. Grass weed control in jute by Targa supef (quizalofop--ethyl 5\% EC). Pestology 28 (2): 31-34.

Ghosh, R. K., Mondal, S. S., Maity, S. 2007. Classification of Herbicides Group. Modern Weed Sci. Manual, pp: 36

Ghosh, S. 2008. Integrated Weed Management of Rapeseed - Soybean crop sequence; Ph.D. Thesis, Department of Agronomy, BCKV (Unpublished).

Gill, G. S. and Vijayakumar. 1969. "Weed index" A new method for reporting weed control trials. Indian J. Agron., 16: 96-98.

Khandakar, A. L. 1985. Screening genotypes for higher harvest index. Ann Report. pp: 158165.

Sahoo, K. M. and Saraswat, V. N. 1988. Magnitude of losses in the yields of major crops due to weed competition in India Pesticide Information, April-June, pp: 2-9.

Saraswat, V. N. 1980. Ecology of weeds of jute fields in India Trop. Pest Management. 26 (1): 45-50.

Saraswat, V. N. 1999. Weed management in jute and jute based cropping system. In: Jute and Allied Fibres Agriculture and Processing, CRIJAF, Barackpore, Golden Jubilee Symposium Publication, pp. 193200.

Saraswat, V. N. and Shanna, D. K. 1983. Comparative efficiency of F1uchloralin and Diphenamid in controlling weeds in jute fields, Pesticides, 17(1): 37-39.

Sarkar, S. 2006. Weed management in jute (Corchorus olitorius L.) by post emergence herbicides. J. Trop. Agric., 44: 71-73.

Sarkar, S. and Majumdar, B. 2013. Herbicidal effect on weed growth, crop yield and soil microbes in olitorius jute (Corchorus olitorius L.) Journal of Trop. Agri., 51 (12): 23 .

\section{How to cite this article:}

Madhab Kumar Datta, Pronobesh Halder, Utpal Biswas and Champak Kumar Kundu. 2017. Effect of Different Weed Management Practices on Growth and Yield of Tossa Jute (Corchorus olitorius) in the New Alluvial Zone of West Bengal, India. Int.J.Curr.Microbiol.App.Sci. 6(11): 1118-1123. doi: https://doi.org/10.20546/ijcmas.2017.611.132 